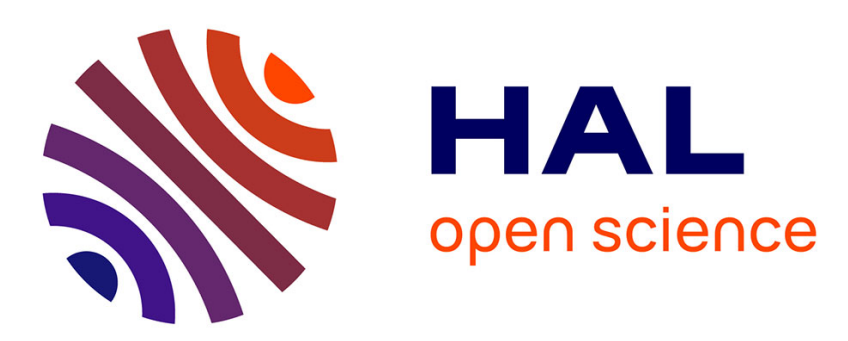

\title{
Cluster Nodes as a Unit for Value Co-creation: The Role of Information Technologies in Competitiveness of the Oil and Gas Industry
}

\author{
Vitaly Ambalov, Irina Heim
}

\section{- To cite this version:}

Vitaly Ambalov, Irina Heim. Cluster Nodes as a Unit for Value Co-creation: The Role of Information Technologies in Competitiveness of the Oil and Gas Industry. 18th International Conference on Informatics and Semiotics in Organisations (ICISO), Jul 2018, Reading, United Kingdom. pp.155-163, 10.1007/978-3-319-94541-5_16. hal-01920721

\section{HAL Id: hal-01920721 \\ https://hal.inria.fr/hal-01920721}

Submitted on 13 Nov 2018

HAL is a multi-disciplinary open access archive for the deposit and dissemination of scientific research documents, whether they are published or not. The documents may come from teaching and research institutions in France or abroad, or from public or private research centers.
L'archive ouverte pluridisciplinaire HAL, est destinée au dépôt et à la diffusion de documents scientifiques de niveau recherche, publiés ou non, émanant des établissements d'enseignement et de recherche français ou étrangers, des laboratoires publics ou privés.

\section{(c)(1)}

Distributed under a Creative Commons Attribution| 4.0 International License 


\title{
Cluster Nodes as a Unit for Value Co-creation: The Role of Information Technologies in Competitiveness of Kazakhstan's Oil and Gas Industry
}

\author{
Vitaly Ambalov ${ }^{1}$ and Irina Heim² ${ }^{2}$ [0000-0003-3023-4839] \\ ${ }^{1}$ National Agency for Development of Local Content, Kazakhstan \\ ${ }^{2}$ Henley Business School, University of Reading, Reading, UK \\ vimsgmegmail.com, i.heimepgr.reading.ac.uk
}

\begin{abstract}
Both the national competitiveness paradigm and cluster theory have prompted decision-makers in emerging countries to take a closer look at the cluster approach, and to consider the possibility of using this approach to boost economic growth. However, this has not led to wider use of cluster analysis as a major instrument for studying complex economic processes in these countries. The reason for this is that the majority of the reviewed concepts of cluster development implemented in emerging countries, such as Kazakhstan and Russia, use of the cluster approach based on foreign experience disregarding the importance of initial local conditions. Thus a more formal study of clusters in emerging countries, taking into account the impact of institutional factors and the individual structural uncertainty of economic systems, recurrent crises and market shocks, is required This research fills the gap by proposing a cluster node as a unit of analysis that allows subdivision of any big industrial and commercial groups, of economic sectors, and of multinational enterprises (MNE) and other structures, into interconnected nodes of a smaller scale, and applying this up to the smallest nodes that are of interest to researchers. This concept will create theoretical foundations for the transformation of national economic clusters, which is strategically important for national governments seeking to attract foreign investments (FDI) and increase local content, thus attracting MNEs to invest in national economies. This research demonstrates how the concept of cluster nodes can be applied to the analysis of linkages between oil and gas industry $(O \& G)$ and industries responsible for the development of information and communication technology (ICT) in Kazakhstan.
\end{abstract}

Keywords: Eclectic Paradigm, Value Co-creation, Clusters, MNEs, ICT, Oil and Gas Industry, Local Content Policy.

\section{Introduction}

The national competitiveness paradigm and cluster theory were introduced by Porter in 1990s $[14 ; 15]$. They are the result of a large-scale research project that led to global changes in the perception of international trade and the manufacturing industry. These 
transformations evolved in the increasing role of specialized firms, and accelerated development of science and technology, in particular in the ICT sector. Simultaneously, the share of R\&D services in the added value had been steadily increasing [2], while the competitiveness of goods and services had come to rely on harmonized cooperation and simultaneous competition of firms as part of an economic cluster. The role of multinational enterprises has changed dramatically. Going beyond national borders MNEs have introduced new products and services into the global market, offering tremendous opportunities to small and medium-sized enterprises that could never before have claimed a share in foreign markets. Such transformations prompted decision-makers in emerging countries to take a closer look at the cluster approach and to consider the possibility of using this approach to boost economic growth.

However, the extensive interest in the cluster approach has not led to wider use of cluster analysis as a major instrument for studying complex economic processes. In emerging countries, a cluster is viewed as a geographically limited association of small and medium-sized enterprises providing services to homogeneous market segments. This has led to mistakes on the side of government decision-makers who seek to create a vertical regulation structure and to implement an industrial policy that views the cluster approach as a concept which has nothing to do with the major economic sectors. In the majority of the reviewed concepts of cluster development implemented in emerging countries, such as Kazakhstan and Russia, the cluster approach is based on copying foreign experience that disregards "the importance of initial conditions and the danger of arguing that one cluster structure is necessarily always more effective than another one" [19]. These circumstances prompt a more formal study of clusters, taking into account the impact of institutional factors and the individual structural uncertainty of economic systems, recurrent crises and market shocks. For the purposes of formalization of cluster systems, we make use of the results of many years of work of international business researchers, and, first and foremost, an eclectic paradigm, which we strongly believe most accurately defines the nature of a company that often acts using apparently incompatible strategies (eclectically), achieving incredible results in an eclectic environment.

\section{Theories and Literature}

\subsection{Theory of Clusters and Competitiveness}

Spatial clustering or agglomeration of firms with similar interests might yield agglomerative economies and an industrial atmosphere, external to the individual firms, but internal to the cluster [8]. The era of alliance capitalism demonstrated the impact of "trans-border elements" on cluster functioning [8;19]. Therefore, it is critical to identify a cluster in which MNE will utilize its own advantages. This identification seems deceptively simple, but in reality, it is a complex task, because there is no definitive and unambiguous understanding of the term "economic cluster". The need for cluster analysis arises when a researcher studying a large system needs to select elements of a certain class from its entire assembly. A classic example is using cluster analysis in order to study country competitiveness. In accordance with the task, Porter [14;15] confined 
the selection of objects for analysis to a specific geographical zone and defined a cluster as a geographically close group of interrelated companies and associated agencies united by common external factors and areas of activity. This definition of competitiveness underpins the concept of the Global Competitiveness Index, reflecting the growing demand to take into account a larger and more complex set of factors that have an impact on a country's prosperity. At present, global organizations work with the definition offered by Porter: "Competitiveness is defined as the set of institutions, policies, and factors that determine the level of productivity. The level of productivity, in turn, sets the sustainable level of prosperity that can be earned by an economy (and) a more competitive economy is one that is likely to grow at larger rates over the medium to long run" [20]. However, many researchers criticize this definition of competitiveness at the macro-level [e.g. 1;12;16] arguing that this gives a distorted picture of competitiveness due to the protectionists regulations used by the countries to protect their markets. For example, Atkinson [1], defines competitiveness as the ability of a nation's non-mineralbased traded sectors to effectively compete in global markets in the absence of subsidies and government protections, while receiving a strong price premium that enables strong terms of trade. The approach suggested by this definition will be used to interpret the increasing competitiveness as a result of value co-creation in clusters.

\subsection{Value Co-creation in Clusters}

Value co-creation is a concept that "encompasses all the specific theoretical and empirical occurrences in which companies and customers generate value through interaction" [21;11]. Co-creation in MNE settings can be defined as the interaction between headquarters, subsidiaries, employees, subcontractors, and customers with each other for the development of new business opportunities [10]. The major actors in the process of value co-creation in MNE settings - Headquarters, Subsidiaries, Employees, Customers and Subcontractors - interact with each other in trying to meet customer expectations. To this end, each of the actors adds value. However, it should be taken into consideration that knowledge of customers' needs is also an important value that plays a crucial role in resource transfer managed by the MNE's subsidiary. The responsibility to do this is delegated to the subsidiary by the headquarters. Each cycle of adding value is preceded by a transaction of resource exchange. We would like to emphasize that the process itself does not create any value for the participants of the value co-creation process. The value is generated once a transaction is complete. Thus, in different periods each of the actors specified by the model can be either a supplier or a recipient of resources.

\subsection{Eclectic Paradigm}

The modern MNE has to be a 'meta-integrator', able to leverage knowledge within and between the different constituent affiliates of its international network, which requires efficient internal markets and well-structured cross-border hierarchies [13]. These empirical findings confirm that the major factors of competitiveness of domestic companies is not protection of the market against MNEs, but rather local content development 
through technological upgrade and growth, based on value co-creation in clusters comprising foreign and indigenous companies.

The study of related literature $[2 ; 9 ; 13]$ and other literature brings us to the conclusion that the eclectic paradigm $[3 ; 4 ; 5 ; 6 ; 7]$, coupled with internalization theory $[17 ; 18]$ is a representative analytical basis for describing structure, and the genesis of economic systems of any tier, not excluding economic clusters of various typologies. The eclectic paradigm is based on three easily definable factors (OLI factors or OLI): the first is the ownership advantage - $\mathrm{O}$, which allows distribution between firms of advantages associated with owning various types of assets. The second is locational advantages $-\mathrm{L}$, which is the advantage of location, such as natural and man-made resources and assets, institutional system of restricting actions of economic actors, as well as factors related to human capital. The third factor is internalization advantages $-\mathrm{I}$, which can be viewed as advantage in terms of systemic links. Inter- and intra-cluster links (I) is one of the important indicators of cluster formation and will be studied in this research.

\section{Theoretical Frameworks}

The abovementioned properties and principles of the eclectic paradigm that bring together numerous heterogeneous elements and arrange them into three uniform groups, create a foundation for introducing a new unit to analyze interrelated industrial and commercial structures; such as industrial agglomerations, economic clusters, and MNEs. The new unit of analysis should encompass company capacities in conjunction with locational and internalization advantages. We use the term cluster node $(\mathrm{CN})$ as such a unit of analysis, where $\mathrm{CN}$ is a set of interdependent factors.

In this research we define cluster node as a dynamic scale-invariant economic OLI system with institutional regulation of internalization of locational advantages (L), in which internalization (I) serves as a link between $\mathrm{L}$ and $\mathrm{O}$ advantages in this location, and a link with other cluster nodes outside this location. The use of a cluster node as a unit of analysis allows division of any large industrial and commercial groups, economic sectors, MNE and other structures into interconnected nodes of a smaller scale and applying this up to the smallest nodes that are of interest to researchers. The typology of the cluster nodes is discussed in the next section (see Table 1 below for definitions).

Investments in national economic cluster are always accompanied either by the internalization of existing cluster nodes, or the appearance of new cluster nodes. Moreover, independent if the investor is local or foreign, they need to exactly identify the type of the cluster node they invest as well as develop the strategy for value co-creation within the national cluster node. This is especially important for MNEs as OLI should best be seen as a way of looking at the phenomenon of multinational enterprises and their activities, resulting in answers on the important questions of MNE activities: why, where and how. Each of these questions can be addressed at a different level: macro, meso or micro [9]. 
Table 1. Classification of cluster nodes. Source: Authors.

\begin{tabular}{|c|c|c|}
\hline Type of a cluster node & Acronym & Definition \\
\hline National economic cluster & $\mathrm{Cn}$ & $\begin{array}{l}\text { Advantages and their owners as well as institutions regulat- } \\
\text { ing internalization in certain countries }\end{array}$ \\
\hline Territorial cluster & $\mathrm{Ct}$ & $\begin{array}{l}\text { Advantages and their owners as well as institutions regulat- } \\
\text { ing internalization in certain territory }\end{array}$ \\
\hline Industry cluster & $\mathrm{Ci}$ & $\begin{array}{l}\text { Actors taking part in value creation of certain types of prod- } \\
\text { ucts }\end{array}$ \\
\hline Clusters alliance & $\mathrm{Ca}$ & $\begin{array}{l}\text { Actors with weak links, interacting and competing with each } \\
\text { other }\end{array}$ \\
\hline Clusters group & $\mathrm{Cg}$ & $\begin{array}{l}\text { Actors with strong links and low competition (hierarchical } \\
\text { corporations, including state-owned holdings) }\end{array}$ \\
\hline Company & $\mathrm{Cc}$ & Company where processes are determined \\
\hline Node process & $\mathrm{Cp}$ & Process performed in a company \\
\hline Clusters skill & Cs & $\begin{array}{l}\text { Person, owner of the technical knowledge and skills required } \\
\text { for successful career in the industry }\end{array}$ \\
\hline
\end{tabular}

Figure 1 below shows the three-level architecture of a national economic cluster, in which a territorial cluster and an industry cluster, complying with restrictions imposed by national and supranational institutions, may have a common coordination body, while the remaining nodes should necessarily conform with the restrictions imposed by regulatory bodies (top officials), or coordinating bodies (the so-called cluster organizations).

The inclusion of people in the typology of clusters (clusters skill/Cs), has a number of significant reasons. The information that is created, accumulated and transferred in the network, the movement of knowledge holders within the created network, as well 


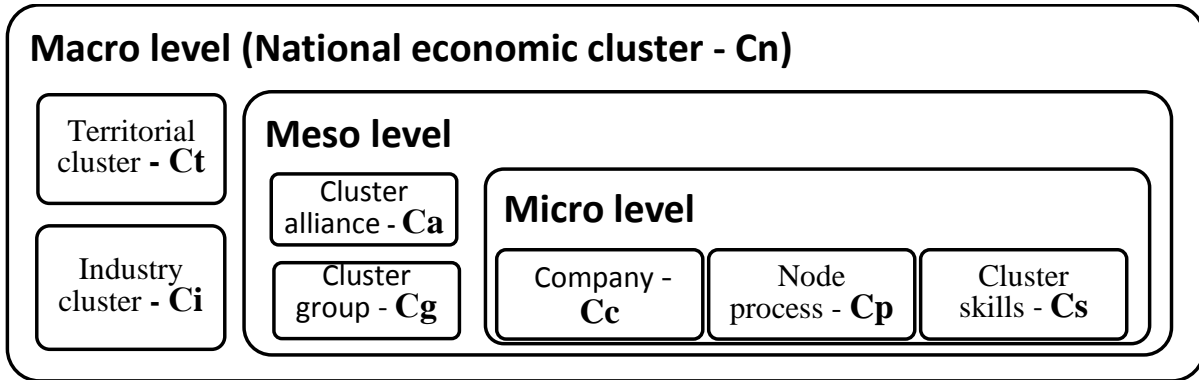

Fig. 1. Architecture of the national economic cluster. Source: Authors.

as internetwork links, all have an impact on the efficiency of the subsidiary and the very MNE that equals, or is even greater, than that of the processes determined by the system. This is the impact of a human being both as an owner and carrier of intellectual property. Therefore, each employee should be viewed as a self-similar and invariant actor of the network communication because the cluster analysis will be incomplete without the intellectual component. Indeed, in any cluster and in any firm, tangible assets and internalization do not make sense without inclusion of the owners/professionals who act as knowledge holders.

The eclectic paradigm does allow one to go a step further by relating the OLI configuration facing MNEs to a number of structural or contextual variables» [5]. This research will adopt the theory of value co-creation [21] as a theoretical lens through which IT-enabled local capabilities development in clusters are explained.

\section{Case Study: Linking Kazakhstan's Oil and Gas and ICT Clusters}

This concept is a promising instrument for optimizing the existing cluster nodes and synthesizing new cluster nodes, including in the complementary O\&G and ICT sectors. The complementarity is based on three factors: (i) digitalization of business and broader use of sensing systems and other high-tech devices, which lead to the accumulation of big data, to be selectively used by managers and technical specialists; (ii) accumulation of big data prompts drastic transformation of the system itself - data as such will be viewed as a valuable source of knowledge about an object and its current status and behavior. This will help to improve the system of quality management, as well as to synthesize innovative tasks and run projects. In other words, there will be integration of all components of two sectors; (iii) a capability to analyze the current status of the system and total automatization of processes, which will gradually erase borders between ICT and business, and emphasize the importance of specialists being able to work with big data.

We study the possibility of increasing the local content and accelerating the growth of the ICT cluster node of Kazakhstan by linking it with the O\&G cluster node, integrating this pool with national clusters of other countries, thus making use of the mutually beneficial cooperation with the unified international cluster system. The cluster 
nodes concept allows cluster analysis to be conducted across selected indices describing competitiveness. In this case we have used one index, namely the index showing the change of the share of products assembled by Kazakhstan's ICT, and consumed by the O\&G industry. Figure 2 below shows the matrix of the current status of the explored system.

\begin{tabular}{|c|c|c|c|}
\hline O Advantages & $\begin{array}{l}\text { O\&G } \\
\text { Business processes, } \\
\text { international transactions, } \\
\text { equipment, ICT }\end{array}$ & $\begin{array}{l}\text { Education } \\
\text { Training of } \\
\text { ICT specialists }\end{array}$ & $\begin{array}{c}\text { Education } \\
\text { and } \\
\text { R\&D } \\
\text { in } \\
\text { ICT and O\&G }\end{array}$ \\
\hline O\&G cluster & $\begin{array}{c}\text { Capital investment: } \\
\$ 26.83 \text { billion } \\
\text { Production volume: } \\
\text { oil - } 86 \text { million tones }(80 \% \text { MNE) } \\
\text { gas }-61.6 \text { billion } \mathrm{m}^{3} \\
\end{array}$ & $\begin{array}{l}13,558 \\
\text { graduates with } \\
\text { degree in } \\
\text { electronics and } \\
\text { ICT } \\
\end{array}$ & $\begin{array}{l}21,269 \\
\text { peopled } \\
\text { employed in } \\
\text { R\&D (all } \\
\text { sectors) }\end{array}$ \\
\hline $\begin{array}{l}\text { Internalization } \\
\text { advantages }\end{array}$ & $\begin{array}{r}\text { Laws and regulation } \\
\text { Local conte } \\
\text { Regional legislation, including } \\
\text { World Trade Orga }\end{array}$ & $\begin{array}{l}\text { aiming to attract } \\
\text { t regulations } \\
\text { Eurasian Econom } \\
\text { ization membersh }\end{array}$ & Commission \\
\hline ICT cluster & $\begin{array}{c}\text { Market size: } \\
\$ 2.68 \text { billion, including: } \\
\text { O\&G cluster is }<10 \% \\
\text { Services and software: } \\
\$ 644 \text { million, or }<25 \% \\
\end{array}$ & \multirow{2}{*}{\multicolumn{2}{|c|}{$\begin{array}{l}\text { Low demand for software and } \\
\text { R\&D specialists, a low number of } \\
\text { software programmers } \\
\text { Insufficient financing of projects to } \\
\text { develop high-technology solutions }\end{array}$}} \\
\hline $\begin{array}{l}\text { O\&G cluster } \\
\text { demand for ICT } \\
\text { products and } \\
\text { services }\end{array}$ & $\begin{array}{l}\text { Added value of products and ser- } \\
\text { vices related to ICT is estimated } \\
\text { to exceed } \$ 1.0 \text { billion }\end{array}$ & & \\
\hline $\begin{array}{l}\text { Number of } \\
\text { specialists in } \\
\text { ICT cluster }\end{array}$ & \multicolumn{3}{|c|}{$\begin{array}{c}\text { Communication: } 34,500 \text { people } \\
\text { Information services: } 7,600 \text { people } \\
\text { Computer programming, consulting and services: } 3,000 \text { people }\end{array}$} \\
\hline $\begin{array}{l}\text { Demand for } \\
\text { human } \\
\text { resources in ICT } \\
\text { cluster }\end{array}$ & \multicolumn{3}{|c|}{$\begin{array}{l}\text { High demand for highly qualified specialists } \\
\text { An outflow of e employees abroad }\end{array}$} \\
\hline
\end{tabular}

Fig. 2. Matrix of the links between two nodes: ICT and O\&G, current status (2017). Source: Authors based on data provided by the Committee on Statistics, the Ministry of National Economy of the Republic of Kazakhstan, RAEX rating agency, Kazakhstan and authors calculations based on media reports.

The matrix is based on official statistical data and information provided by international institutions. These data confirm the country's progress in high-technology sectors. In particular, in line with The Networked Readiness Index 2016, Kazakhstan is ranked 
39th out of 139 countries. Thus, Kazakhstan is ahead of Turkey, Poland and Italy and is close to the Czech Republic in this index [22]. The analysis of the OL matrix reveals that Kazakhstan's cluster nodes responsible for telecommunications and provision of computer equipment and communication facilities are well balanced in terms of supply and demand. Institutions that are necessary for regulation of value co-creation processes in cluster nodes are created (National ICT Holding "Zerde", National Agency for Development of Local Content "NADLoK" and other). However, certain disproportions in the linked nodes have come to the surface. Indeed, the potential demand of Kazakhstan's O\&G industry for computing equipment and services (over $\$ 1$ billion annually) is not yet saturated. This fact allows high-tech companies, including subsoil users, not to consider the ICT cluster node as a partner able to address these needs. At the same time, information and communication technologies for the $\mathrm{O} \& \mathrm{G}$ industry are developed and purchased outside Kazakhstan's CN.

Apart from this, the Ownership-Location matrix demonstrates: (i) weakness of the ICT cluster node responsible for software development, which is a serious challenge for the ongoing local content policy because information technologies are and will be a key instrument for enhancing the performance of the domestic $O \& G$ industry. (ii) another weak point is unavailability of hands-on experience for graduates of new university departments/new universities because of an inadequate number of projects related to development of original IT solutions. At the same time, the launch of new IT projects is prevented by inadequate competencies of programmers. (iii) the country's education system in the ICT field has made considerable progress and domestic universities turn out more graduates for this field than the national economic cluster currently can employ.

Nevertheless, the capacities of the linked nodes of ICT and O\&G can be augmented, if the IT business, supported by government institutions, uses FDI instruments to team up with a developed IT cluster of a country that is similar in culture and other parameters determining distance. In line with the cluster nodes concept, if Kazakhstan's leading IT firms set up subsidiary companies in the countries that have developed IT clusters, the available significant advantages will meet to enable large-scale projects and to provide university graduates with an opportunity to get hands-on experience.

\section{Conclusions}

The traditional approach to studying and defining economic clusters focuses on geographically close groups of companies, and is based on using companies as a unit of analysis. In this work, we suggest the consideration of a cluster as a dynamic OLI system defined as a node, a unit of analysis in a cluster node model. The study of economic clusters in Kazakhstan suggests that competitiveness of clusters is determined by a number of firm specific advantages, available to all cluster participants. The analysis of ICT and O\&G clusters of Kazakhstan reveals that the concept is a promising instrument for optimizing the existing cluster systems and synthesizing new systems. 


\section{References}

1. Atkinson, R. D. The Competitive Edge: A Policymaker's Guide to Developing a National Strategy. ITIF Homepage, http://www.itif.org, last accessed 2018/04/15.

2. Castellani D., M. Piva, T. Schubert, Vivarelli. M. R\&D and Productivity in the US and the EU: Sectoral Specificities and Differences in the Crisis. Henley Business School Homepage, http://www.henley.ac.uk, last accessed 2018/04/15.

3. Dunning, J. H. Toward an eclectic theory of international production: some empirical tests. Journal of International Business Studies 11(1), 9-31 (1980).

4. Dunning, J. H. The eclectic paradigm of international production: a restatement and some possible extensions. Journal of international business studies 19(1), 1-31 (1988).

5. Dunning, J. H. Reappraising the eclectic paradigm in an age of alliance capitalism. In: The Eclectic Paradigm. Palgrave Macmillan, London (1995).

6. Dunning, J. H. The eclectic paradigm as an envelope for economic and business theories of MNE activity. International business review 9(2), 163-190 (2000).

7. Dunning, J. H. Location and the multinational enterprise: a neglected factor? Journal of international business studies 40(1), 5-19 (2000).

8. Dunning, J. H. Regions, globalization, and the knowledge-based economy. Oxford university press, Oxford (2002).

9. Eden, L. A critical reflection and some conclusions on OLI. In: Cantwell, J., Narula, R. (eds.) International business and the eclectic paradigm: developing the OLI framework. Routledge, London (2003).

10. Heim, I., Tian, T., Ghobadian, A. Value co-creation in ICT services company: a case study of a cross-border acquisition. In press (2018). https://doi.org/10.1080/10669868.2018.1467841.

11. Jaakkola, E., Hakanen, T. Value co-creation in solution networks. Industrial Marketing Management 42(1), 47-58 (2013).

12. Krugman P. Competitiveness: a dangerous obsession, Foreign Affairs 73(2), 28-44 (1994).

13. Narula, R. The Modern MNE as an Efficient Meta-integrator: Emerging Market MNEs Need to Foster Internal Embeddedness to Succeed. Henley Business School Discussion Paper (2014). Henley Business School Homepage, http://www.henley.ac.uk, last accessed 2018/04/15.

14. Porter M. The Competitive Advantage of Nations. Harvard Business Review, March-April (1990).

15. Porter, M. On Competition. Boston: Harvard Business School, Cambridge (1998).

16. Psofogiorgos, N-A., Metaxas, T. Porter vs Krugman: history, analysis and critique of regional competitiveness, MPRA Paper 68151. University Library of Munich, Germany (2015).

17. Rugman, A. M. Regional strategy and the demise of globalization. Journal of International Management 9(4), 409-417 (2003).

18. Rugman, A. M. Reconciling internalization theory and the eclectic paradigm. Multinational Business Review 18(2), 1-12 (2010).

19. Rugman, A. M., Verbeke, A. Multinational Enterprises and Clusters: An Organizing Framework. Management International Review 43(3), 151-169 (2003).

20. Snowdon, B. The Enduring Elixir of Economic Growth. World Economics 7(1), 73-130 (2006).

21. Vargo, S. L., Lusch, R. F. Service-dominant logic: continuing the evolution. Journal of the Academy of Marketing Science 36(1), 1-10 (2008). 
22. WEF Homepage, The Global Information Technology Report 2016. World Economic Forum, Geneva. WEF Homepage, https://www.weforum.org/, last accessed 2018/04/15. 